\title{
The effect of body weight on altered expression of nuclear receptors and cyclooxygenase- 2 in human colorectal cancers Barbara Delage ${ }^{1}$, Anne Rullier ${ }^{2}$, Maylis Capdepont ${ }^{3}$, Eric Rullier ${ }^{3}$ and Pierrette Cassand*1
}

\begin{abstract}
Address: ${ }^{1}$ Laboratoire Alimentation et Cancerogenese Colique, Unite de Nutrition et Signalisation Cellulaire, Universite Bordeaux1, France, 2Departement de Pathologie, Hopital Pellegrin, Bordeaux, France and '²Departement de Chirurgie Digestive, Hopital Saint-André, Bordeaux, France
\end{abstract}

Email: Barbara Delage - delage.barbara@laposte.net; Anne Rullier - anne.rullier@chu-bordeaux.fr; Maylis Capdepont - maylis.capdepont@chubordeaux.fr; Eric Rullier - eric.rullier@chu-bordeaux.fr; Pierrette Cassand* - p.cassand@istab.u-bordeaux1.fr

* Corresponding author

Published: 3 September 2007

Nutrition Journal 2007, 6:20 doi:10.1/86/1475-289/-6-20

This article is available from: http://www.nutritionj.com/content/6/I/20

(C) 2007 Delage et al; licensee BioMed Central Ltd.

This is an Open Access article distributed under the terms of the Creative Commons Attribution License (http://creativecommons.org/licenses/by/2.0), which permits unrestricted use, distribution, and reproduction in any medium, provided the original work is properly cited.

\begin{abstract}
Background: Epidemiological studies on risk factors for colorectal cancer (CRC) have mainly focused on diet, and being overweight is now recognized to contribute significantly to CRC risk. Overweight and obesity are defined as an excess of adipose tissue mass and are associated with disorders in lipid metabolism. Peroxisome proliferator-activated receptors (PPARs) and retinoidactivated receptors (RARs and RXRs) are important modulators of lipid metabolism and cellular homeostasis. Alterations in expression and activity of these ligand-activated transcription factors might be involved in obesity-associated diseases, which include CRC. Cyclooxygenase-2 (COX-2) also plays a critical role in lipid metabolism and alterations in COX-2 expression have already been associated with unfavourable clinical outcomes in epithelial tumors. The objective of this study is to examine the hypothesis questioning the relationship between alterations in the expression of nuclear receptors and COX-2 and the weight status among male subjects with CRC.
\end{abstract}

Method: The mRNA expression of the different nuclear receptor subtypes and of COX-2 was measured in 20 resected samples of CRC and paired non-tumor tissues. The association between expression patterns and weight status defined as a body mass index (BMI) was statistically analyzed.

Results: No changes were observed in PPAR $\gamma$ mRNA expression while the expression of PPAR $\delta$, retinoid-activated receptors and COX-2 were significantly increased in cancer tissues compared to normal colon mucosa $(P \leq 0.00 \mathrm{I})$. The weight status appeared to be an independent factor, although we detected an increased level of COX-2 expression in the normal mucosa from overweight patients $(\mathrm{BMI} \geq 25)$ compared to subjects with healthy BMI $(P=0.002)$.

Conclusion: Our findings show that alterations in the pattern of nuclear receptor expression observed in CRC do not appear to be correlated with patient weight status. However, the analysis of COX-2 expression in normal colon mucosa from subjects with a high BMI suggests that COX2 deregulation might be driven by excess weight during the colon carcinogenesis process. 


\section{Background}

Approximately 5\% of individuals will develop colorectal carcinoma during their lifetime [1]. This disease typically progresses from adenomatous polyps and dysplastic polyps to invasive carcinoma [2,3]. CRC seems particularly susceptible to specific nutritional factors and dietary habits (for review [4]). Indeed, excessive consumption of calories from fat is thought to be largely responsible for the increasing incidence of CRC in western countries. Moreover, overweight and obesity status associated with high body mass indices have been correlated with a higher risk of developing CRC $[5,6]$. Nevertheless, the mechanisms of why and how excess weight increases cancer risk are only slowly emerging. One proposed mechanism is the rise of insulin resistance resulting in hyperinsulinemia that can cause growth-promoting effects [7].

Hyperinsulinemia as well as hyperlipidemia, hypertension, overweight and type II diabetes are metabolic disorders which might be caused by alterations in the homeostasis of the metabolism of fatty acids [8]. These obesity-related symptoms could affect the integrity of colon tissue homeostasis and therefore be involved in CRC etiology [9]. Anti-diabetic treatments initially used for improving parameters such as insulin sensitivity have been shown to be able to inhibit colon carcinogenesis in rodent models $[10,11]$ and to promote differentiation of colon cancer cells [12]. Moreover, concomitant suppression of hyperlipidemia and polyp formation were observed in APC-deficient mice treated with insulin-sensitizing drugs called thiazolidinediones (TZD) [13]. In such a context, PPAR family members initially recognized for their involvement in regulating fat metabolism and adipogenesis have emerged as attractive targets for therapeutic approaches for obesity and CRC. Indeed, PPAR $\gamma$ agonists including anti-diabetic agents, polyunsaturated fatty acids as well as non-steroidal anti-inflammatory drugs (NSAID) $[14,15]$ have been demonstrated to affect proliferation and differentiation in cancer cell lines [16]. Moreover, both anti-proliferative effects of PPAR $\gamma$ observed in vitro [12] and inactivating mutations in the PPAR $\gamma$ gene found in colon tumors [17] provide evidence for a tumor suppressor function. This is also supported by the finding that an increased risk of polyp occurrence in colon mucosa was found to be significantly associated with a decrease in PPAR $\gamma$ mRNA expression [18]. Another isotype, PPAR $\delta$, may also play an important role in the process of colon carcinogenesis since it has been efficiently targeted by hypolipidemic and hypoglycemic drugs [19]. However, PPAR $\delta$ might display distinct functions in lipid metabolism and colon carcinogenesis. Indeed and in contrast to PPAR $\gamma$, PPAR $\delta$ was found frequently overexpressed in colon cancer cells [20] and tumors of chemically-initiated animals [21]. Nevertheless, the role of PPAR $\delta$ in colonic epithelium stays unclear due to conflicting evidence [22].

The transcriptional activity of PPAR depends on the presence of the retinoic $\mathrm{X}$ receptor (RXR), activated by 9-cis retinoic acid (9-cis RA). Heterodimerization with RXR is essential for the activity of all class II nuclear receptors [23] and explains how fatty acids and retinoids control lipid metabolism [24]. The active forms of vitamin A, 9-cis RA and all-trans retinoic acid (atRA), also exhibit antitumoral properties in many tissues mainly through RXR and retinoic acid-activated receptor (RAR) binding. Indeed, retinoids have displayed chemopreventive and chemotherapeutic activities with regard to their capacity to induce cell differentiation and apoptosis (for review [25]). RXR $\alpha$ is by far the most prevalent isoform in the colon, while RXR $\beta$ and RXR $\gamma$ are expressed at low levels [26]. All three RAR isotypes, $\alpha, \beta$, and $\gamma$, are expressed and induced by retinoids in colon cancer cell lines [27]. Alterations in retinoid-activated receptor expression and biological activity have been observed both in vivo and in vitro [28]. However, potential alterations have been poorly investigated in CRC although they may affect the response of target cells to retinoid and lipid derivatives.

COX-2 is a key enzyme in lipid metabolism and is wellknown to convert arachidonic acid to growth-regulating molecules such as prostaglandins. COX-2, activated by growth factors and pro-inflammatory cytokines, has been shown to be overexpressed in several epithelial cancers including CRC $[29,30]$. This enzyme might mediate the promotion of colon carcinogenesis by metabolic disorders and inflammation and several lines of evidence indicate that COX-2 might be regulated by PPAR $\gamma$ [31] and RAR $\beta$ activation in cancer cells [32,33] although the mechanism is unclear. It was also shown that deregulations in nuclear receptor expression might promote COX2 upregulation [34].

In the current report, our interest was (i) to evaluate alterations in the expression of the different nuclear receptors and COX-2 in several colon cancer specimens from patients undergoing surgery to remove tumors and (ii) to clarify whether or not the expression of nuclear receptors and COX-2 was affected by the weight status of patients with CRC.

\section{Methods}

\section{Patients and samples}

Tumor samples and normal adjacent tissue microscopically confirmed to be free of cancer were obtained from 20 patients undergoing surgery for colorectal cancer at the St. André Hospital (Bordeaux, France) from January 2003 to September 2004. Following surgery, samples from tumor and adjacent normal mucosa were frozen in liquid nitro- 
gen and stored at $-80^{\circ} \mathrm{C}$ for subsequent RNA extraction. All included patients were men without neoadjuvant treatment. Patients suffering from familial cancer syndromes were excluded. Information concerning age, BMI (weight $(\mathrm{kg}) /$ height $(\mathrm{m})^{2}$ ), tumor site, pTNM and Dukes stage are indicated in Table 1. BMI was found not to be correlated with height in this population $(r=0.07, \mathrm{n}=$ $20)$, but strongly correlated with weight $(r=0.89, \mathrm{n}=20)$. Segregation of patients into BMI groups corresponded to the following categorizations: $18.5-25 \mathrm{~kg} / \mathrm{m}^{2}$ (healthy weight), $\geq 25 \mathrm{~kg} / \mathrm{m}^{2}$ (excess weight group including overweight/pre-obese/obese subjects).

\section{RNA extraction and reverse transcription (RT)}

Total RNA was extracted from colon tissue samples using the RNAgents Total RNA Isolation System kit according to the manufacturer's instructions (Promega, Charbonnières, France). Reverse transcription was as follows: $2 \mu \mathrm{g}$ of total RNA was mixed with RNasin $(1 \mathrm{U} / \mu \mathrm{L}$, Promega, Charbonnières, France) and DNase I (0.5 U/ $\mu \mathrm{L}$, Roche Diagnostics, Meylan, France) and incubated $15 \mathrm{~min}$ at $37^{\circ} \mathrm{C}$. Reverse primers $(0.75 \mu \mathrm{M}$ of each $)$ were added and incubated for $10 \mathrm{~min}$ at $70^{\circ} \mathrm{C}$. ImProm- $\mathrm{II}^{\mathrm{TM}} 5 \times$ reaction buffer (1×, Promega, Charbonnières, France), $\mathrm{MgCl}_{2}(2.5$ $\mathrm{mM}$, Promega, Charbonnières, France), dNTP (0.5 mM each one, Roche Diagnostics, Meylan, France) and ImProm-II ${ }^{\mathrm{TM}}$ Reverse Transcriptase (Promega, Charbonnières, France) were added for $1 \mathrm{hr}$ at $42^{\circ} \mathrm{C}$. The total volume was $20 \mu \mathrm{L}$ and each target mRNA was co-reverse transcribed with $\beta 2$-microglobulin mRNA.

\section{Real-time Polymerase Chain Reaction (PCR)}

Real-time quantitative PCR involving LightCycler ${ }^{\mathrm{rM}}$ technology (Roche Diagnostics, Mannheim, Germany), was performed according to the protocol recommended by the manufacturer and previously described [34]. SYBR green I fluorescence dye was sufficiently sensitive to accurately detect amplified products from all target cDNA (PPAR $\delta$, PPAR $\gamma$, RAR $\alpha, R X R \alpha$ and COX-2) except for RAR $\beta$ and RAR $\gamma$ amplified product detected using dual-labeled and specific TaqMan fluorogenic probes. Quantification data were analyzed using the LightCycler Relative Quantification Software (Roche Diagnostics, Mannheim, Germany). The software provides a crossing point (Cp), defined as the PCR cycle number, function of the log of the DNA concentration (in ng). A standard curve is a plot of the Cp versus the amount of initial cDNA used for amplification. Standard curves were used to estimate the concentration of both the target and the reference gene in each sample. This software provides a calibrator-normalized relative quantification including PCR efficiency correction considering then the difference existing between amplification efficiencies of reference and target cDNAs. cDNA from tissue samples from patient A was arbitrarily chosen to be the calibrator. The cDNA calibrator was used in all experiments. Results are expressed as the target:reference ratio divided by the target:reference ratio of the calibrator. Primers and fluorogenic probes were purchased from Proligo France (Paris, France). Each probe was synthesized with the fluorescent reporter dye FAM (6-carboxy-fluorescein) attached to the 5'-end and a quencher dye TAMRA

Table I: Summary of clinical and pathological data

\begin{tabular}{|c|c|c|c|c|c|c|c|}
\hline Case $n^{\circ}$ & Age & $\mathrm{BMI}$ & $\mathrm{T}^{\mathrm{a}}$ & $\mathrm{Na}^{\mathrm{a}}$ & $\mathrm{Ma}^{\mathrm{a}}$ & Dukes $^{b}$ & Site \\
\hline I & 80 & 20.83 & 4 & I & $x$ & $C$ & asc. colon \\
\hline 2 & 80 & 29.75 & 3 & I & $x$ & $C$ & asc. colon \\
\hline 3 & 72 & 38.75 & 3 & I & $x$ & $C$ & rectum \\
\hline 4 & 82 & 31.41 & 3 & 0 & $x$ & B & rectum \\
\hline 5 & 81 & 21.47 & 3 & 0 & $x$ & B & sigmoid \\
\hline 6 & 69 & 25.34 & 3 & 0 & $x$ & B & asc. colon \\
\hline 7 & 56 & 24.68 & 3 & I & I & D & asc. colon \\
\hline 8 & 66 & 21.91 & 3 & 0 & $x$ & B & asc. colon \\
\hline 9 & 69 & 24.34 & 4 & I & $x$ & $C$ & rectum \\
\hline 10 & 86 & 24.91 & 4 & I & I & $\mathrm{D}$ & asc. colon \\
\hline 11 & 87 & 23.03 & 3 & I & $x$ & $C$ & rectum \\
\hline 12 & 66 & 27.68 & 4 & 0 & $x$ & B & sigmoid \\
\hline 13 & 73 & 28.13 & 4 & I & $x$ & $C$ & sigmoid \\
\hline 14 & 71 & 34.60 & 3 & I & $x$ & $C$ & rectum \\
\hline 15 & 60 & 30.24 & 2 & 0 & 1 & D & sigmoid \\
\hline 16 & 61 & 26.12 & 3 & 0 & $x$ & B & sigmoid \\
\hline 17 & 41 & 18.73 & 4 & I & $x$ & $C$ & asc. colon \\
\hline 18 & 85 & 25.95 & 3 & I & $x$ & $C$ & asc. colon \\
\hline 19 & 72 & 29.06 & 2 & 0 & I & D & des.colon \\
\hline 20 & 76 & 22.72 & 3 & I & I & $\mathrm{D}$ & rectum \\
\hline
\end{tabular}

a According to the TNM classification : T, primary tumor; N, regional lymph nodes; M, metastasisb According to the Dukes classification

b According to the Dukes classification 
(6-carboxy-tetramethyl-rhodamine) to the 3'-end. Specificity of primers was validated through the verification of RT-PCR product specificity. RT-PCR products were subjected to analysis by electrophoresis on a 1.5\% agarose gel and resulted in a single product with the desired length ( $\beta 2$-microglobulin, 112 bp; PPAR $\delta, 139$ bp; PPAR $\gamma, 144$ bp; RAR $\alpha, 235$ bp; RAR $\beta, 133$ bp; RAR $\gamma, 167$ bp; RXR $\alpha$, $142 \mathrm{bp}$; COX-2, $130 \mathrm{bp}$ ). The identity of amplified products were assessed by sequencing with a Dye Terminator Reaction Cycle Kit (Perkin-Elmer, Norwalk, CT) and were analyzed on an ABI PRISM ${ }^{\mathrm{TM}} 377$ automated DNA sequencer (Perkin-Elmer). The forward and reverse primer sequences and the probes were as follows:

32-microglobulin: sense 5' CTTGGGCTGTGACAAAGTC 3', antisense 5' GTCTTTC-AGCAAGGACTGG 3', Taqman probe $\quad 5^{\prime}$ (6-Fam)TGGTTCACTCGGCAGGCATACTC(Tamra) 3';

PPAR $\delta$ : sense 5'GGGAGAGGTCTGTGTAGCTGCTG 3', antisense 5' ATGGAGCA-GCCACAGGAGGAAGCC 3';

PPAR $\gamma$. sense 5' CGGATGGCCACCTCTTTGCTC 3', antisense 5' GGCGAGGGCG-ATCTTGACAGG 3';

RAR $\alpha$ : sense 5' ACGTTGTTCTGAGCTGTTGTTCGTA 3', antisense 5' CTGCCAGT-ACTGCCGACTGC 3';

RAR $\beta$ : sense 5' AG-GCTTGCTGGGTCGTCTTT 3', antisense 5' CCTTCTCAGTGC-CATCTGCTTAAT 3', Taqman probe $\quad 5^{\prime}$ (6-Fam)AGACCGCCAGGACCTTGAGGAACCGA(Tamra) 3';

$R A R \gamma$. sense 5' GCAAAGACAAGGTCTGT-GAG 3', antisense 5' GACCAGATCAC-TCTGCTCAAAGC 3', Taqman probe $\quad 5^{\prime}$ (6-Fam)TATCCTGATGCTGCGTATCTGCACAAGGT(Tamra);
RXR $\alpha$ : sense 5' GAGCAGCTTATTCCAGCCTGCC 3', antisense 5' CGACCCTGTC-ACCAACATTTGC 3';

COX-2: sense 5'TGGTGCCTGGTCTGATGAT 3', antisense 5' GCCTGCTTGTCTG-GAACAAC 3'

\section{Statistical methods}

Statistical analyses were carried out using the Windows SPSS $^{\circledast} 9.0$ software package. Associations between clinicopathological variables (age, TNM and Dukes stage (Dukes $\mathrm{B}$ vs. C vs. D), BMI (BMI < 25 vs. $\mathrm{BMI} \geq 25)$, tumor site (descendant/sigmoid colon/rectum $v$ s. ascendant colon)) were assessed by Spearman's correlation coefficient test. Associations between mRNA expression levels were tested for correlation by Spearman's test and mRNA levels were compared with regard to clinicopathological features. Specifically, comparison of mRNA expression levels in healthy tissue with regard to BMI and tumor site was performed using the Mann-Whitney U test. The Kruskal-Wallis test was used to assess for significant differences in mRNA expression with regard to Dukes stage (Dukes B $v$ s. $\mathrm{C} v$ s. D). The significance of differences in mRNA expression levels between healthy mucosa and tumor tissue was evaluated using the Wilcoxon-test. A $P$ value $<0.05$ was considered as significant.

\section{Results}

Samples of CRC specimens and adjacent non-neoplastic colonic mucosa were collected from patients undergoing surgery. Pertinent clinical and pathological data are listed in Table 1. All patients were men with a median age of 72 years old (range 41-87). Six patients (30\%) had Dukes' B tumors, nine patients (45\%) were classified as Dukes' C or as Dukes' D (25\%). Eleven patients (55\%) had a BMI greater than 25, and were designated as overweight. Four of these had a BMI value above 30, corresponding to obesity status. No correlation was found between age, BMI, and tumor classification.

Table 2: Nuclear receptor and COX-2 mRNA expression in colorectal tumors

\begin{tabular}{|c|c|c|c|c|c|c|}
\hline \multirow[t]{2}{*}{ Gene } & \multirow[t]{2}{*}{$\mathrm{n}$} & \multicolumn{2}{|c|}{ Normal colon mucosa } & \multicolumn{2}{|c|}{ Tumor tissue } & \multirow[t]{2}{*}{$\mathrm{P}^{\mathrm{a}}$} \\
\hline & & Median & Range & Median & Range & \\
\hline $\operatorname{PPAR} \gamma$ & 20 & 0.96 & $(0.35-3.19)$ & 1.04 & $(0.28-4.71)$ & n.s. \\
\hline PPAR $\delta$ & 20 & 1.30 & $(0.69-2.34)$ & 1.54 & $(0.40-4.96)$ & 0.001 \\
\hline $\mathrm{R} \times \mathrm{R} \alpha$ & 20 & 0.75 & $(0.20-1.25)$ & 0.95 & $(0.21-3.49)$ & $<0.001$ \\
\hline $\mathrm{RAR} \alpha$ & 20 & 1.13 & $(0.69-1.88)$ & 1.44 & $(0.38-3.93)$ & $<0.001$ \\
\hline RAR $\beta$ & 20 & 1.42 & $(0.12-5.39)$ & 2.20 & $(0.18-10.82)$ & $<0.001$ \\
\hline $\mathrm{RAR} \gamma$ & 20 & 1.37 & $(0.49-9.52)$ & 3.42 & $(0.83-15.80)$ & $<0.001$ \\
\hline COX-2 & 20 & 1.50 & $(0.44-6.75)$ & 12.80 & $(0.50-560.5)$ & $<0.001$ \\
\hline
\end{tabular}

Statistical analyses were performed using Wilcoxon-test n.s. not significant

a Wilcoxon test 
Table 3: Associations between nuclear receptor and COX-2 expression in healthy colorectal mucosa

\begin{tabular}{|c|c|c|c|c|c|c|c|}
\hline & $\operatorname{PPAR} \gamma$ & PPAR $\delta$ & $\mathrm{R} \times \mathrm{R} \alpha$ & RAR $\alpha$ & RAR $\beta$ & RAR $\gamma$ & COX-2 \\
\hline $\operatorname{PPAR} \gamma$ & 1.000 & 0.104 (n.s.) & $0.324(0.012)^{a}$ & 0.107 (n.s.) & $0.330(0.010)$ & -0.017 (n.s.) & 0.170 (n.s.) \\
\hline PPAR $\delta$ & & 1.000 & 0.179 (n.s.) & $0.277(0.032)$ & -0.001 (n.s.) & -0.119 (n.s.) & -0.145 (n.s.) \\
\hline$R \times R \alpha$ & & & 1.000 & $0.255(0.049)$ & 0.233 (n.s.) & 0.111 (n.s.) & 0.003 (n.s.) \\
\hline $\mathrm{RAR} \alpha$ & & & & 1.000 & $0.2580(0.046)$ & -0.112 (n.s.) & 0.134 (n.s.) \\
\hline RAR $\beta$ & & & & & 1.000 & $-0.294(0.023)$ & 0.173 (n.s.) \\
\hline RAR $\gamma$ & & & & & & 1.000 & $0.261(0.044)$ \\
\hline COX-2 & & & & & & & 1.000 \\
\hline
\end{tabular}

Nuclear receptors and COX-2 were detectable by quantitative real-time RT-PCR in all normal-looking tissue and tumor samples. The median mRNA expression values are shown in Table 2. The median relative PPAR $\gamma$ expression level in tumors remained unchanged as compared to normal mucosa. Indeed, among 20 investigated cancer tissue samples, PPAR $\gamma$ increased between 1.5- and 4-fold in 35\% $(\mathrm{n}=7)$, while we noted a 1.5 - to 6 -fold decrease in $25 \%$ $(n=5)$. No changes were observed in the remaining $40 \%$ $(\mathrm{n}=8)$. In contrast, the expression of PPAR $\delta$ in tumors was significantly upregulated $(1.54$ vs. $1.30, P=0.001)$ relative to normal mucosa. All retinoid nuclear receptors were also upregulated in tumor tissues compared to healthy mucosa $(\mathrm{n}=20, P<0.001)$. Expression levels were increased by the following percentages: RXR $\alpha$ 26.7\%, RAR $\alpha 27.4 \%$, RAR $\beta$ 54.9\%, and RAR $\gamma$ 149.6\%. COX-2 mRNA expression was multiplied by 8.5 between normal and tumor tissues $(P<0.001)$. Relationships between nuclear receptor and COX-2 mRNA expression were tested statistically and listed in Tables 3 and 4 (see also additional file 1). Further combined analysis of receptor and COX-2 mRNA expression levels with regard to Dukes' stages and tumor localisations did not display any significant statistical difference. COX-2 expression was not correlated with tumor stages and localisations (data not shown), but was associated with RAR $\alpha$ and RAR $\beta$ mRNA expression in tumor tissue (Table 4 ).
Differences in expression of nuclear receptors and COX-2 between normal and tumor tissues (Table 2) were also observed when patients were segregated into groups with low and high BMI (BMI $<25$ vs. BMI $\geq 25$ ) (Tables 5 and $6)$. We also compared the expression of nuclear receptors and COX-2 in healthy mucosa regarding the BMI of patients (Table 7). Statistics revealed that COX-2 expression is significantly increased in the normal-looking mucosa from patients with the highest BMI (Table 7).

\section{Discussion}

Nuclear receptors are involved in many cellular processes from embryonic development to cell death. Dysfunction of nuclear receptor signaling can lead to proliferative and metabolic diseases such as cancer and obesity. In the current report, we assessed the mRNA expression levels of nuclear receptors and COX-2 in 20 CRC specimens and sought a possible relationship with patient's weight status defined by BMI ranging from 18.7 to 38.7 .

PPAR $\gamma$ constitutes the most extensively studied of the three PPAR subtypes $(\alpha, \beta, \gamma)$ since its function relates to lipid metabolism as well as cell differentiation, apoptosis and cancer. PPAR $\gamma$ can be activated by certain lipids and derivatives and by anti-diabetic agents. Activated PPAR $\gamma$ has been shown able to stimulate differentiation and apoptosis in cancer cells from various origins [35-38]. Nevertheless, in contrast with results generated in vitro, data concerning PPAR $\gamma$ expression in human cancer spec-

Table 4: Associations between nuclear receptor and COX-2 expression in colorectal tumors

\begin{tabular}{|c|c|c|c|c|c|c|c|}
\hline & $\operatorname{PPAR} \gamma$ & PPAR $\delta$ & $\mathrm{R} \times \mathrm{R} \alpha$ & RAR $\alpha$ & RAR $\beta$ & $\mathrm{RAR} \gamma$ & COX-2 \\
\hline PPAR $\gamma$ & 1.000 & $\begin{array}{l}0.390 \\
(0.002)^{a}\end{array}$ & $\begin{array}{l}0.364 \\
(0.004)\end{array}$ & $0.408(0.001)$ & 0.105 (n.s.) & $0.436(<0.001)$ & -0.191 (n.s.) \\
\hline PPAR $\delta$ & & 1.000 & $\begin{array}{l}0.620 \\
(<0.001)\end{array}$ & $0.773(<0.001)$ & $0.57 \mathrm{I}(<0.00 \mathrm{I})$ & $0.601(<0.001)$ & 0.407 (n.s.) \\
\hline$R \times R \alpha$ & & & 1.000 & $0.577(<0.001)$ & $0.438(<0.001)$ & $0.425(0.001)$ & 0.161 (n.s.) \\
\hline $\operatorname{RAR} \alpha$ & & & & 1.000 & $0.58 \mathrm{I}(<0.00 \mathrm{I})$ & $0.538(<0.00 \mathrm{I})$ & $0.291(0.024)$ \\
\hline RAR $\beta$ & & & & & 1.000 & $0.434(0.001)$ & $0.453(<0.001)$ \\
\hline $\mathrm{RAR} \gamma$ & & & & & & 1.000 & 0.202 (n.s.) \\
\hline cox-2 & & & & & & & 1.000 \\
\hline
\end{tabular}

n.s. not significant

a correlation coefficient with the $p$ value from Spearman's test in parentheses 
Table 5: Nuclear receptor and COX-2 mRNA expression in colorectal tumors of patients with BMI $<25$

\begin{tabular}{|c|c|c|c|c|c|c|}
\hline \multirow[t]{2}{*}{ Gene } & \multirow[t]{2}{*}{$\mathrm{n}$} & \multicolumn{2}{|c|}{ Healthy colon mucosa } & \multicolumn{2}{|c|}{ Tumor tissue } & \multirow[t]{2}{*}{$\mathrm{P}^{\mathrm{a}}$} \\
\hline & & Median & Range & Median & Range & \\
\hline $\operatorname{PPAR} \gamma$ & 9 & 1.00 & $(0.65-3.19)$ & 1.17 & $(0.35-3.67)$ & n.s. \\
\hline PPAR $\delta$ & 9 & 1.35 & $(0.69-2.34)$ & 1.55 & $(0.57-4.96)$ & 0.012 \\
\hline $\mathrm{R} \times \mathrm{R} \alpha$ & 9 & 0.76 & $(0.37-1.20)$ & 1.09 & $(0.54-1.84)$ & $<0.001$ \\
\hline RAR $\alpha$ & 9 & 1.09 & $(0.69-1.85)$ & 1.58 & $(0.95-3.93)$ & $<0.001$ \\
\hline RAR $\beta$ & 9 & 1.53 & $(0.52-2.49)$ & 2.78 & $(0.18-8.49)$ & 0.001 \\
\hline $\mathrm{RAR} \gamma$ & 9 & 1.21 & $(0.76-3.68)$ & 4.49 & $(0.91-9.68)$ & $<0.001$ \\
\hline COX-2 & 9 & 1.11 & $(0.5 \mathrm{I}-3.48)$ & 12.40 & $(0.50-560.46)$ & $<0.001$ \\
\hline
\end{tabular}

imens raised questions about the anti-neoplastic activity of the receptor in vivo. For example, PPAR $\gamma$ was found highly expressed in ovarian carcinoma [39] and its overexpression in pancreatic carcinoma was associated with poor prognosis [40]. By contrast, our data, in agreement with others [41], showed PPAR $\gamma$ expression globally unchanged in CRC compared with adjacent normal tissues, although Dubois et al. [42] found a marked increase of PPAR mRNA expression in four CRC samples and in different colon cancer cell lines. Discrepancies might be attributed to germline mutations in the adenomatous polyposis gene (APC). Indeed, PPAR $\gamma$ has been involved in increasing resistance towards carcinogens by preventing the accumulation of $\beta$-catenin, which is regulated by APC. However, PPAR $\gamma$ functions are lost when APC is mutated [43]. Another report has shown that deregulated APC/ $\beta$-catenin indirectly induced aberrant PPAR $\gamma$ overexpression [44], explaining previous experimental data in $A P C^{\mathrm{Min} /+}$ - mice showing a promoting effect of PPAR $\gamma$ on carcinogenesis [45]. This has relevance for humans because mutations in the tumor suppressor gene APC are the initiating event in about $85 \%$ of sporadic CRC. Therefore, APC status could dramatically affect expression and function of PPAR $\gamma$ and the steady-state levels of PPAR $\gamma$ reported here do not exclude loss of PPAR $\gamma$ transcriptional activity due to somatic mutations [17], alterations in intracellular distribution [46], post-translation modifications [47] or inhibition by PPAR $\delta$ [48].
Like PPAR $\gamma, \operatorname{PPAR} \delta$ gene expression is detected in the colon and the receptor can be activated by fatty acids and derivatives. Herein, we reported an elevated level of PPAR $\delta(\sim 18 \%)$ in CRC. Upregulation of PPAR $\delta$ gene expression might be attributed to deregulation in the APC/ $\beta$-catenin pathway since PPAR $\delta$ is considered to be a downstream target gene [20]. Increased levels of PPAR $\delta$ expression have already been observed in rodent colorectal tumors and in primary human colorectal adenocarcinomas $[20,21]$. Nevertheless, PPAR $\delta$ function remains elusive, with data showing that PPAR $\delta$ was dispensable for polyp formation [49]. Our data and others suggested a contribution of PPAR $\delta$ in the carcinogenesis process $[16,50]$ while Marin et al. [22] described that agonist-activated PPAR $\delta$ protects against cancer development. As for $\operatorname{PPAR} \gamma$, the integrity of the tumor suppressor APC might be essential to guarantee PPAR $\delta$ normal function.

Critical to the transcriptional activity of PPARs is the ability to form a complex with RXR and bind to DNA. Synthetic ligands of RXR $\alpha$ were shown to exhibit insulinsensitizing activity $[51,52]$ and to act synergistically with PPAR $\gamma$ ligands to enhance PPAR $\gamma /$ RXR $\alpha$-mediated transactivation [31]. In addition, a positive correlation in healthy mucosa was found between RXR $\alpha$ and PPAR $\gamma$ supporting the idea of a tight relationship in the regulation of the expression of these receptors. While no change in RXR $\alpha$ expression level was previously noted in 17 patients with CRC [41], our data revealed a significant increase in tumor

Table 6: Nuclear receptor and COX-2 mRNA expression in colorectal tumors of patients with BMI $\geq 25$

\begin{tabular}{|c|c|c|c|c|c|c|}
\hline \multirow[t]{2}{*}{ Gene } & \multirow[t]{2}{*}{$\mathrm{n}$} & \multicolumn{2}{|c|}{ Healthy colon mucosa } & \multicolumn{2}{|c|}{ Tumor tissue } & \multirow[t]{2}{*}{$\mathrm{P}^{\mathrm{a}}$} \\
\hline & & Median & Range & Median & Range & \\
\hline $\operatorname{PPAR} \gamma$ & 11 & 0.95 & $(0.35-2.11)$ & 0.97 & $(0.28-4.71)$ & n.s. \\
\hline PPAR $\delta$ & II & 1.28 & $(0.72-2.00)$ & 1.52 & $(0.40-4.49)$ & 0.022 \\
\hline $\mathrm{R} \times \mathrm{R} \alpha$ & 11 & 0.64 & $(0.20-1.25)$ & 0.85 & $(0.21-3.49)$ & 0.047 \\
\hline $\operatorname{RAR} \alpha$ & 11 & 1.17 & $(0.72-1.88)$ & $\mathrm{I} .44$ & $(0.38-3.72)$ & 0.018 \\
\hline RAR $\beta$ & 11 & 1.30 & $(0.12-5.39)$ & 2.12 & $(0.24-10.82)$ & 0.014 \\
\hline $\operatorname{RAR} \gamma$ & 11 & 1.60 & $(0.49-9.52)$ & 3.17 & $(0.83-15.80)$ & $<0.001$ \\
\hline $\operatorname{cox}-2$ & 11 & 2.93 & $(0.44-6.75)$ & 13.20 & $(0.85-166.86)$ & $<0.001$ \\
\hline
\end{tabular}


Table 7: Comparison between nuclear receptor and COX-2 mRNA expression in healthy colorectal mucosa from patients with BMI < 25 or with BMI $\geq 25$

\begin{tabular}{|c|c|c|c|c|c|c|c|}
\hline \multirow[t]{2}{*}{ Gene } & \multicolumn{3}{|c|}{$\mathrm{BMI}<25$} & \multicolumn{3}{|c|}{$\mathrm{BMI} \geq 25$} & \multirow[t]{2}{*}{$\mathrm{P}^{\mathrm{a}}$} \\
\hline & $\mathrm{n}$ & Median & Range & $\mathrm{n}$ & Median & Range & \\
\hline PPAR $\gamma$ & 9 & 1.00 & $(10.65-3.19)$ & 11 & 0.95 & $(0.35-2.11)$ & n.s. $(0.882)$ \\
\hline PPAR $\delta$ & 9 & 1.35 & $(0.69-2.34)$ & 11 & 1.28 & $(0.72-2.00)$ & n.s.(0.882) \\
\hline$R \times R \alpha$ & 9 & 0.76 & $(0.37-1.20)$ & 11 & 0.64 & $(0.20-1.25)$ & n.s.(0.095) \\
\hline $\operatorname{RAR} \alpha$ & 9 & 1.09 & $(0.69-1.85)$ & 11 & 1.17 & $(0.72-1.88)$ & n.s. $(0.824)$ \\
\hline RAR $\beta$ & 9 & 1.53 & $(0.52-2.49)$ & 11 & 1.30 & $(0.12-5.39)$ & n.s. $(0.370)$ \\
\hline $\mathrm{RAR} \gamma$ & 9 & 1.21 & $(0.76-3.68)$ & 11 & 1.60 & $(0.49-9.52)$ & n.s. $(0.230)$ \\
\hline cox-2 & 9 & 1.11 & $(0.51-3.48)$ & 11 & 2.93 & $(0.44-6.75)$ & 0.002 \\
\hline
\end{tabular}

Statistical analyses were performed using Mann-Whitney test

n.s. not significant

a Mann-Whitney test

versus normal tissue. A similar upregulation was also observed in human esophageal [53], breast [54] and hepatocellular carcinomas [32]. However, little is known about the function of RXR $\alpha$ in colon tumorigenesis and our results do not rule out the possibility of alterations in $\operatorname{RXR} \alpha$ functions due to altered localization [55] or inhibitory effect of unliganded RXR $\alpha$ on PPAR $\gamma$ transactivation [56].

Recent data have also suggested that PPAR $\gamma$ anti-tumor activity required a functional RAR $\beta$ [57]. This implies that PPAR $\gamma$ function may be affected by alterations in the retinoid pathway. To our knowledge, very few reports have examined the expression of retinoid receptors in CRC. Therefore, we described here the first detailed analysis of nuclear receptor RAR $\alpha, \beta$ and $\gamma$ mRNA expression in CRC. RAR $\beta$ has been extensively studied in cancer cells and human carcinomas, and several studies have suggested that it may play a role as a tumor suppressor gene [58-60]. However, our results showed a significant upregulation in the expression of all three RAR isotypes in CRC specimens compared to adjacent normal mucosa. Furthermore, we showed a complex association between the expression of mRNA for RXR $\alpha$, RARs, and PPARs in cancer tissue, suggesting interactions and cross-talk between these receptors in tumorigenesis. These results demonstrated that alterations are not restricted to a single receptor. Instead, we observed a profound dysregulation of the retinoid pathway in this CRC. Downregulation of mRNA expression of RAR $\beta$ often observed in cancer cells has been considered as a cellular mechanism to prevent retinoid-induced growth arrest $[61,62]$. On the other hand, while elevated levels of RAR mRNA expression has also been described in breast, liver and esophageal tumors [53,63,64], mechanism and significance are unknown. Nevertheless, if the expression of RAR correlates with tissue sensitivity to retinoids, our results should be confirmed within a larger number of samples and both the mechanism leading to inappropriate RXR and RAR expression and the response of CRC to retinoids should be investigated.

There are strong correlations between the intake of fatty acids, the establishment of metabolic disorders and an increased risk of developing CRC $[65,66]$. This suggests the involvement of PPARs and retinoid receptors, activated by fatty acids and derivatives [21] and modulated by metabolic disorders [67] in establishing a link between overweight prevalence and CRC pathogenesis. In the current report, we aimed to clarify whether aberrations in the expression of nuclear receptors may contribute to associate high BMI and CRC. However, alterations in nuclear receptor expression observed in tumors were similar in both patients with low or high BMI. We also investigated COX-2 expression which is involved in cellular responses to lipids and inflammatory processes that favour tumorigenesis by stimulating cell proliferation and angiogenesis [68]. Interestingly, while COX-2 was greatly expressed in CRC as previously shown [69], we also found a significantly increased level of COX-2 expression in normal mucosa from patients with high BMI compared to low BMI patients. Recently, it has been reported that patients with a high risk of developing CRC presented an upregulation of the COX-2 gene in normal-looking colon mucosa [70]. This supports the idea that COX-2 deregulation might be an early event in the process of carcinogenesis. Nevertheless, although previous reports showed COX-2 regulation by nuclear receptors $[31,71]$, very few associations were found in our study between COX-2 and nuclear receptor expression. In conclusion, our study described altered expression of nuclear receptors in CRC specimens. Further studies are warranted in order to determine the underlying mechanism leading to altered expression of PPARs and retinoid-activated receptors and the significance of such alterations. Moreover, alterations in nuclear receptor expression were independent of the weight status of patients. Nevertheless, COX-2 might be 
one early target influenced by excess weight and associated metabolic disorders and consequently might affect nuclear receptor expression and activation.

\section{Authors' contributions}

$\mathrm{BD}$ and PC designed the research plan; AR and ER provided and analyzed specimens (histopathology); BD performed research; MC performed statistical analyses; $\mathrm{BD}$ and $\mathrm{PC}$ analyzed data; and $\mathrm{BD}$ wrote the paper. All authors read and approved the final manuscript.

\section{Additional material}

\section{Additional file 1}

Associations between mRNA expression levels of PPAR, RXR and RAR subtypes in CRC. CC : correlation coefficient; $p: p$ value based on Spearman's test. The figure provided represents the statistical analyses of the correlations between nuclear receptor expression in colorectal tumors. Click here for file

[http://www.biomedcentral.com/content/supplementary/14752891-6-20-S1.ppt]

\section{Acknowledgements}

The Ligue Régionale Contre le Cancer - Comités Aquitaine Charentes financially supported this study.

\section{References}

I. Jemal A, Tiwari RC, Murray T, Ghafoor A, Samuels A, Ward E, Feuer EJ, Thun MJ: Cancer statistics, 2004. CA Cancer J Clin 2004, 54(I):8-29.

2. Fearon ER, Vogelstein B: A genetic model for colorectal tumorigenesis. Cell 1990, 61 (5):759-767.

3. Kinzler KW, Vogelstein B: Lessons from hereditary colorectal cancer. Cell 1996, 87(2):159-I70.

4. Ahmed FE: Effect of diet, life style, and other environmental/ chemopreventive factors on colorectal cancer development, and assessment of the risks. J Environ Sci Health C Environ Carcinog Ecotoxicol Rev 2004, 22(2):9|-|47.

5. Bianchini F, Kaaks R, Vainio H: Overweight, obesity, and cancer risk. Lancet Oncol 2002, 3(9):565-574.

6. Calle EE, Rodriguez C, Walker-Thurmond K, Thun MJ: Overweight, obesity, and mortality from cancer in a prospectively studied cohort of U.S. adults. N Engl J Med 2003, 348(17): 1625-I638.

7. Giovannucci E: Nutrition, insulin, insulin-like growth factors and cancer. Horm Metab Res 2003, 35( I I-I 2):694-704.

8. Haffner $\mathrm{S}$, Taegtmeyer $\mathrm{H}$ : Epidemic obesity and the metabolic syndrome. Circulation 2003, 108(13): I54|-I545.

9. Suehiro T, Matsumata T, Shikada Y, Sugimachi K: Hyperinsulinemia in patients with colorectal cancer. Hepatogastroenterology 2005, 52(6I):76-78.

10. Osawa E, Nakajima A, Wada K, Ishimine S, Fujisawa N, Kawamori T, Matsuhashi N, Kadowaki T, Ochiai M, Sekihara H, Nakagama H: Peroxisome proliferator-activated receptor gamma ligands suppress colon carcinogenesis induced by azoxymethane in mice. Gastroenterology 2003, I 24(2):361-367.

II. Popovich IG, Zabezhinski MA, Egormin PA, Tyndyk ML, Anikin IV, Spasov AA, Semenchenko AV, Yashin Al, Anisimov VN: Insulin in aging and cancer: antidiabetic drug Diabenol as geroprotector and anticarcinogen. Int $J$ Biochem Cell Biol 2005, 37(5): $1117-1129$.

12. Yoshizumi T, Ohta T, Ninomiya I, Terada I, Fushida S, Fujimura T, Nishimura G, Shimizu K, Yi S, Miwa K: Thiazolidinedione, a peroxisome proliferator-activated receptor-gamma ligand, inhibits growth and metastasis of HT-29 human colon cancer cells through differentiation-promoting effects. Int J Oncol 2004, 25(3):63I-639.

13. Niho N, Takahashi M, Kitamura T, Shoji Y, Itoh M, Noda T, Sugimura $\mathrm{T}$, Wakabayashi K: Concomitant suppression of hyperlipidemia and intestinal polyp formation in Apc-deficient mice by peroxisome proliferator-activated receptor ligands. Cancer Res 2003, 63( I 8):6090-6095.

14. Kliewer SA, Sundseth SS, Jones SA, Brown PJ, Wisely GB, Koble CS, Devchand $P$, Wahli W, Willson TM, Lenhard JM, Lehmann JM: Fatty acids and eicosanoids regulate gene expression through direct interactions with peroxisome proliferator-activated receptors alpha and gamma. Proc Natl Acad Sci U S A 1997, 94(9):43।8-4323.

15. Lehmann JM, Lenhard JM, Oliver BB, Ringold GM, Kliewer SA: Peroxisome proliferator-activated receptors alpha and gamma are activated by indomethacin and other non-steroidal antiinflammatory drugs. J Biol Chem 1997, 272(6):3406-3410.

16. Wang T, Xu J, Yu X, Yang R, Han ZC: Peroxisome proliferatoractivated receptor gamma in malignant diseases. Crit $R e v$ Oncol Hematol 2006, 58(I): I- 14 .

17. Sarraf P, Mueller E, Smith WM, Wright HM, Kum JB, Aaltonen LA, de la Chapelle A, Spiegelman BM, Eng C: Loss-of-function mutations in PPAR gamma associated with human colon cancer. $\mathrm{Mol}$ Cell 1999, 3(6):799-804.

18. Bogazzi F, Ultimieri F, Raggi F, Costa A, Gasperi M, Cecconi E, Mosca F, Bartalena L, Martino E: Peroxisome proliferator activated receptor gamma expression is reduced in the colonic mucosa of acromegalic patients. J Clin Endocrinol Metab 2002, 87(5):2403-2406.

19. Desvergne B, Wahli W: Peroxisome proliferator-activated receptors: nuclear control of metabolism. Endocr Rev 1999 , 20(5):649-688.

20. He TC, Chan TA, Vogelstein B, Kinzler KW: PPARdelta is an APC-regulated target of nonsteroidal anti-inflammatory drugs. Cell 1999, 99(3):335-345.

21. Gupta RA, Tan J, Krause WF, Geraci MW, Willson TM, Dey SK, DuBois RN: Prostacyclin-mediated activation of peroxisome proliferator-activated receptor delta in colorectal cancer. Proc Natl Acad Sci U S A 2000, 97(24): I 3275-I3280.

22. Marin HE, Peraza MA, Billin AN, Willson TM, Ward JM, Kennett MJ, Gonzalez FJ, Peters JM: Ligand activation of peroxisome proliferator-activated receptor beta inhibits colon carcinogenesis. Cancer Res 2006, 66(8):4394-440 I.

23. Rastinejad F: Retinoid $\mathbf{X}$ receptor and its partners in the nuclear receptor family. Curr Opin Struct Biol 200 I, I I(I):33-38.

24. Keller H, Dreyer C, Medin J, Mahfoudi A, Ozato K, Wahli W: Fatty acids and retinoids control lipid metabolism through activation of peroxisome proliferator-activated receptor-retinoid X receptor heterodimers. Proc Natl Acad Sci U S A 1993, 90(6):2160-2164

25. Brtko J, Thalhamer J: Renaissance of the biologically active vitamin A derivatives: established and novel directed therapies for cancer and chemoprevention. Curr Pharm Des 2003, 9(25):2067-2077.

26. Kane KF, Langman MJ, Williams GR: I,25-Dihydroxyvitamin D3 and retinoid $X$ receptor expression in human colorectal neoplasms. Gut 1995, 36(2):255-258.

27. Stewart LV, Thomas ML: Retinoids differentially regulate the proliferation of colon cancer cell lines. Exp Cell Res 1997, 233(2):321-329.

28. Sun SY, Lotan R: Retinoids and their receptors in cancer development and chemoprevention. Crit Rev Oncol Hematol 2002, $4|(I): 4|-55$.

29. Kutchera W, Jones DA, Matsunami N, Groden J, Mclntyre TM, Zimmerman GA, White RL, Prescott SM: Prostaglandin H synthase 2 is expressed abnormally in human colon cancer: evidence for a transcriptional effect. Proc Natl Acad Sci U S A 1996, 93(10):4816-4820.

30. Wolff $H$, Saukkonen K, Anttila S, Karjalainen A, Vainio H, Ristimaki A: Expression of cyclooxygenase-2 in human lung carcinoma. Cancer Res 1998, 58(22):4997-500I.

31. Yang WL, Frucht $\mathrm{H}$ : Activation of the PPAR pathway induces apoptosis and COX-2 inhibition in HT-29 human colon cancer cells. Carcinogenesis 200I, 22(9): I379-I 383.

32. Adachi S, Okuno M, Matsushima-Nishiwaki R, Takano Y, Kojima $S$, Friedman SL, Moriwaki H, Okano Y: Phosphorylation of retinoid 
$X$ receptor suppresses its ubiquitination in human hepatocellular carcinoma. Hepatology 2002, 35(2):332-340.

33. Eisinger AL, Nadauld LD, Shelton DN, Peterson PW, Phelps RA, Chidester S, Stafforini DM, Prescott SM, Jones DA: The adenomatous polyposis coli tumor suppressor gene regulates expression of cyclooxygenase-2 by a mechanism that involves retinoic acid. J Biol Chem 2006, 28 I (29):20474-20482.

34. Delage B, Bairras C, Buaud B, Pallet V, Cassand P: A high-fat diet generates alterations in nuclear receptor expression: prevention by vitamin $A$ and links with cyclooxygenase- 2 and beta-catenin. Int J Cancer 2005, I l 6(6):839-846.

35. Chang TH, Szabo E: Induction of differentiation and apoptosis by ligands of peroxisome proliferator-activated receptor gamma in non-small cell lung cancer. Cancer Res 2000, 60(4): $1129-1138$.

36. Takashima T, Fujiwara Y, Higuchi K, Arakawa T, Yano Y, Hasuma T, Otani S: PPAR-gamma ligands inhibit growth of human esophageal adenocarcinoma cells through induction of apoptosis, cell cycle arrest and reduction of ornithine decarboxylase activity. Int J Oncol 200I, 19(3):465-47I.

37. Brockman JA, Gupta RA, Dubois RN: Activation of PPARgamma leads to inhibition of anchorage-independent growth of human colorectal cancer cells. Gastroenterology 1998, I I 5(5): 1049-1055.

38. Yang YC, Tsao YP, Ho TC, Choung IP: Peroxisome proliferatoractivated receptor-gamma agonists cause growth arrest and apoptosis in human ovarian carcinoma cell lines. Int J Gynecol Cancer 2007, 17(2):418-425.

39. Zhang GY, Ahmed N, Riley C, Oliva K, Barker G, Quinn MA, Rice GE: Enhanced expression of peroxisome proliferator-activated receptor gamma in epithelial ovarian carcinoma. $\mathrm{Br} /$ Cancer 2005, 92(I): II3-119.

40. Kristiansen G, Jacob J, Buckendahl AC, Grutzmann R, Alldinger I, Sipos B, Kloppel G, Bahra M, Langrehr JM, Neuhaus P, Dietel M, Pilarsky $C$ : Peroxisome proliferator-activated receptor gamma is highly expressed in pancreatic cancer and is associated with shorter overall survival times. Clin Cancer Res 2006, I 2(2I):6444-645I.

41. Feilchenfeldt J, Brundler MA, Soravia C, Totsch M, Meier CA: Peroxisome proliferator-activated receptors (PPARs) and associated transcription factors in colon cancer: reduced expression of PPARgamma-coactivator I (PGC-I). Cancer Lett 2004, 203(I):25-33.

42. DuBois RN, Gupta R, Brockman J, Reddy BS, Krakow SL, Lazar MA: The nuclear eicosanoid receptor, PPARgamma, is aberrantly expressed in colonic cancers. Carcinogenesis 1998, 19(I):49-53.

43. Girnun GD, Smith WM, Drori S, Sarraf P, Mueller E, Eng C, Nambiar P, Rosenberg DW, Bronson RT, Edelmann W, Kucherlapati R, Gonzalez FJ, Spiegelman BM: APC-dependent suppression of colon carcinogenesis by PPARgamma. Proc Natl Acad Sci U S A 2002, 99(2I): I 377|-| 3776.

44. Jansson EA, Are A, Greicius G, Kuo IC, Kelly D, Arulampalam V, Pettersson $\mathrm{S}$ : The $\mathrm{Wnt} /$ beta-catenin signaling pathway targets PPARgamma activity in colon cancer cells. Proc Natl Acad Sci U S A 2005, 102(5): | 460-| 465 .

45. Lefebvre AM, Chen I, Desreumaux P, Najib J, Fruchart JC, Geboes K, Briggs M, Heyman R, Auwerx J: Activation of the peroxisome proliferator-activated receptor gamma promotes the development of colon tumors in C57BL/6J-APCMin/+ mice. Nat Med 1998, 4(9): 1053-1057.

46. Nomura S, Nakajima A, Ishimine S, Matsuhashi N, Kadowaki T, Kaminishi M: Differential expression of peroxisome proliferator-activated receptor in histologically different human gastric cancer tissues. J Exp Clin Cancer Res 2006, 25(3):443-448.

47. Fu M, Wang $C$, Zhang $X$, Pestell RG: Acetylation of nuclear receptors in cellular growth and apoptosis. Biochem Pharmacol 2004, 68(6): I I99-I 208.

48. Shi Y, Hon M, Evans RM: The peroxisome proliferator-activated receptor delta, an integrator of transcriptional repression and nuclear receptor signaling. Proc Natl Acad Sci U S A 2002, 99(5):26|3-26|8

49. Barak Y, Liao D, He W, Ong ES, Nelson MC, Olefsky JM, Boland R, Evans RM: Effects of peroxisome proliferator-activated receptor delta on placentation, adiposity, and colorectal cancer. Proc Natl Acad Sci U S A 2002, 99(I):303-308.
50. Park BH, Vogelstein B, Kinzler KW: Genetic disruption of PPARdelta decreases the tumorigenicity of human colon cancer cells. Proc Natl Acad Sci U S A 200I, 98(5):2598-2603.

5I. Mukheriee R, Davies PJ, Crombie DL, Bischoff ED, Cesario RM, Jow L, Hamann LG, Boehm MF, Mondon CE, Nadzan AM, Paterniti JR Jr., Heyman RA: Sensitization of diabetic and obese mice to insulin by retinoid $X$ receptor agonists. Nature 1997 386(6623):407-4I0.

52. Shen Q, Cline GW, Shulman GI, Leibowitz MD, Davies PJ: Effects of rexinoids on glucose transport and insulin-mediated signaling in skeletal muscles of diabetic (db/db) mice. J Biol Chem 2004, 279(19): | 972|-|9731.

53. Kumar A, Kaur J, Chattopadhyay TK, Mathur M, Ralhan R: Differential expression of retinoic acid receptors in normal and malignant esophageal tissues. J Exp Ther Oncol 2004, 4(I): I-8.

54. Friedrich M, Axt-Fliedner R, Villena-Heinsen C, Tilgen W, Schmidt W, Reichrath J: Analysis of vitamin D-receptor (VDR) and retinoid X-receptor alpha in breast cancer. Histochem J 2002, 34(I2):35-40.

55. Tanaka T, Dancheck BL, Trifiletti LC, Birnkrant RE, Taylor BJ, Garfield $\mathrm{SH}$, Thorgeirsson U, De Luca LM: Altered localization of retinoid $X$ receptor alpha coincides with loss of retinoid responsiveness in human breast cancer MDA-MB-23 I cells. Mol Cell Biol 2004, 24(9):3972-3982.

56. Monden T, Yamada M, Nihei Y, Kishi M, Tomaru T, Ishii S, Hashida T, Shibusawa N, Hashimoto K, Satoh T, Kasai K, Mori M: Unliganded RXR acts as an inhibitory factor on troglitazone-induced activation. Life Sci 2004, 76(7):73|-74I.

57. James SY, Lin F, Kolluri SK, Dawson MI, Zhang XK: Regulation of retinoic acid receptor beta expression by peroxisome proliferator-activated receptor gamma ligands in cancer cells. Cancer Res 2003, 63( I3):353 I-3538.

58. Arapshian A, Kuppumbatti YS, Mira-y-Lopez R: Methylation of conserved $\mathrm{CpG}$ sites neighboring the beta retinoic acid response element may mediate retinoic acid receptor beta gene silencing in MCF-7 breast cancer cells. Oncogene 2000, 19(35):4066-4070.

59. Cote S, Sinnett D, Momparler RL: Demethylation by 5-aza-2'deoxycytidine of specific 5-methylcytosine sites in the promoter region of the retinoic acid receptor beta gene in human colon carcinoma cells. Anticancer Drugs 1998, 9(9):743-750.

60. Virmani AK, Rathi A, Zochbauer-Muller S, Sacchi N, Fukuyama Y, Bryant D, Maitra A, Heda S, Fong KM, Thunnissen F, Minna JD, Gazdar AF: Promoter methylation and silencing of the retinoic acid receptor-beta gene in lung carcinomas. J Natl Cancer Inst 2000, 92(16): $1303-1307$.

6I. Emionite L, Galmozzi F, Grattarola M, Boccardo F, Vergani L, Toma $S$ : Histone deacetylase inhibitors enhance retinoid response in human breast cancer cell lines. Anticancer Res 2004, 24(6):4019-4024

62. Lee MO, Han SY, Jiang S, Park JH, Kim SJ: Differential effects of retinoic acid on growth and apoptosis in human colon cancer cell lines associated with the induction of retinoic acid receptor beta. Biochem Pharmacol 2000, 59(5):485-496.

63. Sano K, Takayama T, Murakami K, Saiki I, Makuuchi M: Overexpression of retinoic acid receptor alpha in hepatocellular carcinoma. Clin Cancer Res 2003, 9( I O Pt I):3679-3683.

64. van der Leede BM, Geertzema J, Vroom TM, Decimo D, Lutz Y, van der Saag PT, van der Burg B: Immunohistochemical analysis of retinoic acid receptor-alpha in human breast tumors: retinoic acid receptor-alpha expression correlates with proliferative activity. Am J Pathol 1996, I48(6): | 905-1914.

65. Heo M, Allison DB, Fontaine KR: Overweight, obesity, and colorectal cancer screening: disparity between men and women. BMC Public Health 2004, 4(I):53.

66. Lin J, Zhang SM, Cook NR, Rexrode KM, Lee IM, Buring JE: Body mass index and risk of colorectal cancer in women (United States). Cancer Causes Control 2004, I 5(6):58I-589.

67. Basu TK, Basualdo C: Vitamin A homeostasis and diabetes mellitus. Nutrition 1997, 13(9):804-806.

68. Trifan OC, Hla T: Cyclooxygenase-2 modulates cellular growth and promotes tumorigenesis. J Cell Mol Med 2003, 7(3):207-222.

69. Sano H, Kawahito Y, Wilder RL, Hashiramoto A, Mukai S, Asai K, Kimura S, Kato H, Kondo M, Hla T: Expression of cyclooxygen- 
ase-1 and -2 in human colorectal cancer. Cancer Res 1995 , 55( I 7):3785-3789.

70. Hao CY, Moore DH, Wong P, Bennington JL, Lee NM, Chen LC: Alteration of gene expression in macroscopically normal colonic mucosa from individuals with a family history of sporadic colon cancer. Clin Cancer Res 2005, I I (4): I 400-I 407.

7I. Glinghammar B, Skogsberg J, Hamsten A, Ehrenborg E: PPARdelta activation induces COX-2 gene expression and cell proliferation in human hepatocellular carcinoma cells. Biochem Biophys Res Commun 2003, 308(2):36I-368.

Publish with Bio Med Central and every scientist can read your work free of charge

"BioMed Central will be the most significant development for disseminating the results of biomedical research in our lifetime. "

Sir Paul Nurse, Cancer Research UK

Your research papers will be:

- available free of charge to the entire biomedical community

- peer reviewed and published immediately upon acceptance

- cited in PubMed and archived on PubMed Central

- yours - you keep the copyright
BioMedcentral 